International Journal of Language, Literature and Gender Studies (LALIGENS), Ethiopia

Vol. 5 (1), Serial No 11, February, 2016: 26-34

ISSN: 2225-8604(Print) ISSN 2227-5460 (Online)

DOI: http://dx.doi.org/10.4314/laligens.v5i1.3

\title{
Rural Women Education in Rivers State: Challenges and Prospects
}

\author{
Iyalla-Amadi, Priye E., Ph.D. \\ Department of French, \\ Ignatius Ajuru University of Education, \\ Port Harcourt, Rivers State \\ E-mail: priyei@yahoo.com
}

\begin{abstract}
The rural milieu could be described, in economic and social terms, as a rustic and unsophisticated locale lacking in urban features. Literacy, leading to education, on the other hand, is a sophisticated activity that acts as the gateway to modern living and makes way for economic and social enhancement. Women, considered the weaker sex in many parts of the world, including Rivers State, are usually not exposed to such sophisticated activities as literacy and education, more especially those living in the rural areas. Yet, they are caught up in an era that requires the sophistication of modernity in order to survive economically, socially and otherwise. This article seeks to examine the challenges confronting the education of women in the rural areas of Rivers State, and to point out the prospects for educating the rural womenfolk in the state. It also proffers suggestions that can accomplish the goal of an educated female citizenry, keeping well in mind that, women, whether rural or urban, are the procreators and purveyors of any generation at any point in history.
\end{abstract}

\section{Introduction}

The challenge of educating rural women in a state with a rugged topography like Rivers State can be very daunting. The state itself could almost-be described as a 
one-city state with very few industrialized places, yet it has 23 Local Government Areas (LGAs) with an overall estimated population of 5.6million people (Rivers State Ministry of Information and Communication, 2010). Women are expectedly more than half this population. Port Harcourt, the state capital and perhaps Obio/Akpor L.G.A., are the main township areas, the other 21 L.G.As are scattered all over the state.

The outlay of the state can be said to be in two categories: upland and riverine. The LGAs in the upland category are: Abua/Odual, Ahoada East, Ahoada West, Eleme, Emohua, Etche, Gokana, Ikwerre, Khana, Obio/Akpor, Ogba/Egbeme/Ndoni (partly riverine), Omuma, Oyigbo, Port Harcourt and Tai; while the LGAs that can be categorized as riverine are AkukuToru, Andoni, Asari-Toru, Bonny, Degema, Ogu/Bolo, Okrika and Opobo/Nkoro. This is why the state is often geographically described as having topography of flat plains with a network of rivers and tributaries.

The challenge is therefore to carry basic education to as many women as possible in all corners of the state, no matter how remote or "inaccessible" the location. Educating women, especially the rural women or Rivers State, translates to educating the upcoming children of the state because, wherever there are women, there children are to be found, and where children are found, there too can be found whole generations of future leaders to be trained, nurtured and educated.

\section{Steps Taken So Far}

It should be mentioned that the Rivers State government has not been insensitive to the plight of non-literate in its domain. In the year 2004, the then state government identified with a Non-governmental organization called the Rural Women Literacy Project and commissioned it to go into various LGAs and educate women. A coordinator was appointed, who in turn appointed other sub-coordinators to facilitate the task at hand. The mandate of the organization was to ensure literacy and numeracy among the non-literate women of the state in the shortest possible time.

The strategy employed by the body was to identify the three senatorial districts in the state and ensure even distribution of literacy services as it went long. The senatorial districts in Rivers State and the LGAs comprising them are as follows: (1) Rivers West Senatorial district: Abua/Odual, Ahoada East, Ahoada West, Akuku-Toru, Asari-Toru, Bonny, Degema and Ogba/Egbema/Ndoni; (2) Rivers East Senatorial district: Emohua, Etche, Ikwerre, Obio/Akpor, Ogu/Bolo, Okrika and Omuma and Port Harcourt; (3) Rivers South-East: Andoni, Eleme, Gokana, Khana, Opobo/Nkoro, Oyigbo and Tai.

Thus, approximately 33 learning centres were set up in at least four LGAs in each senatorial district. These learning centres were centrally placed to serve as many communities as possible, so that, for example, the Learning centre at Akabuka in Ogba/Egbema LGA served the towns of Obuburu, Obrikom, Ubeta and Akabuka itself. 
Using this method, the 33 Learning Centres were able to serve 86 communities with a total of about 3,347 women being taught in a short time.

Challenges of Rural Women Education as mentioned before, the terrain of the state is very rugged, whether in the upland or the riverine areas. To reach women in Opobo/Nkoro LGA, for example, one has to contend with villages that are only accessible by boat, and some others by crudely made canoes without engines. Travelling to these places means leaving early enough to be able to return before nightfall and thus requires taking the boat on a charter basis where it does not fill up in time.

The point mentioned above leads to another challenge of teaching the women before nightfall. Since most rural areas, because of little or no industrial presence, do not have infrastructural amenities, power is often lacking to light up the classrooms at night. Now, many rural women are also the breadwinners of their various households and can only be available in the evening to learn. As a matter of fact, a research conducted to study the rate of literacy among adult literacy students in an urban area, such as Port Harcourt township, and those located in a rural area, such as Beere in Khana LGA, showed that the adult students in the Port Harcourt LGA had the advantage of studying up till $9.00 \mathrm{pm}$ because of the presence of electricity in their classrooms (Iyalla-Amadi, 2009).

While in the riverine communities, the challenge is accessing the area by boat or canoe, in the upland places, the nature of the soil can pose a problem. In Joinkrama, for example, a town just after Akinima, the headquarter of Ahoada West LGA, the soil is such that when it rains, it becomes very smooth and glue-like so that, even for pedestrians, rain boots are needed to maintain traction. There were instances of the project vehicle sinking in the mud and needing the joint efforts of the women pupils and their husbands to be pushed out!

Yet another challenge as concerns non-literate women in the rural areas is the high incidence of conception among them. Lack of education often leads to early marriage or early pregnancy with marriage. The result is that, many of the girl-women to be taught are constrained by early motherhood, and so are unable to complete the course of study. To solve the problem some attend classes with their young babies in tow, thereby being a source of distractions to other learners in the class.

At the economic level, there are also challenges. In fact, Sharma (2010) has identified poverty as the foremost factor limiting female education. This is buttressed by the fact that rural women have very low purchasing power mainly because their enterprise is often at a low level; small-scale fishing (the men go further upstream for bigger fish), periwinkle-picking, vegetable, okra or pepper farming petty trading, and the like. This means that the income generated is often too insignificant to purchase 
learning materials, such that, they would rather do without the learning materials than part with their little income.

In general, non-literate rural women could be placed in three categories: a) young women who went into marriage and child-bearing early; b) middle-aged women who had to drop out of school early because of lack of money or so that their male siblings could be educated; c) women of advance age who yearn for education and seize the chance whenever it presents itself. These three categories of women often find themselves in the same class where they all present different types of challenges which the discerning teacher would have to design solutions for.

One of the major challenges pertaining to the above is that most middle-aged to advanced women are prone to a particular eye condition referred to as presbyopia. It is an age-related condition that results in diminished vision as one gets older. Such women have difficulty in seeing things written on the blackboard or in reading their books without aided vision. This problem is usually compounded by the late-hour teaching in fading light and no electric lighting.

The above list is not exhaustive but rather gives a brief overview of the kinds of challenges one encounters while embarking on the education of women in the rural areas of the state.

\section{A Case Study}

To bring the practical challenges of teaching women in the rural environment into focus, a case study of a typical inspection trip to a learning centre would be presented in this section.

The setting is Angulama, a riverine town in Asari-Toru LGA of Rivers State. To get there, the coordinator, on a routine inspection, parks her vehicle at a side road just before the town of Ido, a short distance from Buguma main town. A short trek takes the coordinator and her assistant to a rickety makeshift jetty from where they take a canoe to a small fishing settlement. A longer trek leads and wait for it to fill up. It is getting late, so the coordinator pays for the remaining seats and asks the driver to take off. The boat takes them to yet another community called Omekwe-Ama. They are directed to the motorcycle park where two unsteady-looking motorbikes are parked, waiting for passengers. They ask to board and are told that the driver whose turn it is has gone to his house, not too far away. Someone volunteers to call him and the driver arrives, rubbing his eyes, signalling that he had probably been sleeping. The coordinator and her assistant are told that they need to wait for a third person to complete the number to be carried to Angulama. The coordinator offers to pay for the third seat and the journey finally begins. The bush path they have to drive through is winding, very sandy and rocky in some places. The coordinator and her assistant get thrown off the motorbike about two times. The second time, the assistant sustains some 
bruises where she fell on her elbow. The driver simply mutter 'sorry' under his breath and continues the ride.

They arrive at the learning Centre housed in the Community Primary School building to find only three women in the class with the teacher. The teacher, who lives in the community, is instructed to gather the other women. In the meantime, arrangements are made for the motorbike driver to wait and take the coordinator and her assistant back after the inspection. The teacher goes out, bell in hand, ringing and calling out to the women to come to school. Some hurriedly put away their fishing baskets, grab a scarf or a clean wrapper, and hurry to school. Some are still clad in the attire worn to the periwinkle marsh or the fishing creek.

Finally, about seven to eleven women are present. The coordinator greets them: 'Good day, class". They reply: "Good day, auntie". The coordinator then asks: "How are you, today?" Some women pupils reply: "Fine", some others reply, "We dey fine".

Coordinator: You have to say: "We are fine, thank you".

Women pupils repeat: We are fine, thank you. The coordinator then taps the table three times and says: "All stand. The national anthem".

The women stand erect, sing the national anthem and recite the pledge. The coordinator congratulates the women and commends the teacher for teaching them well. She then turns to the class:

Coordinator: Bring out your exercise books. (Pupils bring out their exercise books, some looking tattered). Coordinator: Why is your exercise book so tattered?

Woman pupil (speaking Pidgin): Na my pikin dey play with am.

Coordinator: No, you mustn't let your children touch your exercise book. It is for you. Woman pupil: Yes, ma.

The coordinator writes some words on the blackboard and asks the women to read or repeat the words after her:

$1^{\text {st }}$ Woman pupil: I no dey see o!

$2^{\text {nd }}$ Woman pupil: My eye dey pain me.

$3^{\text {rd }}$ Women pupil: I fit read, I will try.

The coordinator then turns to the class teacher and asks her if that is how they normally complain about words written on the blackboard. The teacher replies in the affirmative and says some have dropped out because of that problem. The coordinator asks how the teacher has been coping, she answers that she encourages them to come 
to class earlier in the day before it gets too dark, and she writes in very bold letters on the board. The coordinator then turns to the class again:

Coordinator: OK, I will write the words very big. Anybody that can write them in her book will get a free exercise book and a free pencil.

Many hands go up. There is more interest shown and many visibly try to write the words correctly. The coordinator goes round, inspecting their work and giving words of encouragement. Two women are given free exercise books and pencils for making no mistake while writing. Most of the letters are irregular but legible. The coordinator looks at her watch, it is almost $6 \mathrm{pm}$. She taps the table three times to catch the women's attention.

Coordinator: All stand. Goodbye, class.

Women pupils: God bless you, too.

Coordinator: Class dismissed.

Women pupils: Away!

The coordinator and her assistant, escorted by the class teacher and some women pupils, hurriedly leave the school and look for the motorcycle driver. They find him and he drives them back to the waterside in Omekwe-Ama through the same rough terrain. There are a few near falls as his tyres slide in the thick sand or hit some rocks. They barely catch the last boat back to the fishing settlement from where they frantically look for a canoe to cross to where their vehicle is parked. By this time, it is getting quite dark and they hurry through the farm path to the main road. The driver heaves a sign of relief upon sighting them and they too are quite happy to have made the trip back before complete darkness.

\section{Towards Educating the Rural Woman}

At this point, the question may be posed, why focus on only women? Some answers may be found in a study carried out by IFAD (International Fund for Agricultural Development) on rural poverty in 2001 (IFAD, 2001). The study showed that women were restricted in many areas economically, and that all this had a negative impact on their access to education. The Report noted, among other things, that women:

1) may not control land on which they could make independent farming decisions, or have access to credit, other inputs or tools, which would allow them to apply their knowledge to increase productivity and yields;

2) usually face extra disadvantages and discrimination in labour markets; and

3) are often inhibited by cultural stereotypes and social attitudes from taking on new tasks and responsibilities that are considered in the male domain. 
To make education available to the rural woman therefore, the economic dimension must be taken into account. For example, it was noted earlier that rural women are either small or zero-income earners. Any sustainable educational programme being provided by any organized body would therefore have to be given free of charge. The success recorded by the earlier mentioned NGO, the Rural Women Literacy Project, was predicated on the fact that all learning materials, including school bags, were provided free of charge. This removed a first impediment and allowed more women to participate.

It is important to ensure continuous teaching for tangible impact. To this end, instructors should be sourced from within the community so that they can be close at hand to provide instructive assistance whenever needed. This would be of benefit to both parties as, together, the teacher and the women pupils can agree on a convenient time for teaching and learning to take place.

Another very important aspect that could make teaching rural women a viable reality is the administration of eye care to the women to be taught. As mentioned earlier, and as demonstrate during the case study, many off the women, due to advancing age and other reasons, suffer from poor eyesight. These reasons range from the harsh living conditions of rural women such as excessive exposure to firewood smoke during cooking, to long hours spent in the sun during farming.

From all that has been said above, it is somewhat clear that additional care needs to be taken to achieve viable result when educating rural women. However, all must be done in a spirit of sincerity to actualize what will be best for the state and for the coming generations through laying a proper educational foundation.

\section{Conclusion}

According to Kofi Anan, former Secretary-General of the United Nations (1997-2006), literacy is a bridge from misery to hope. It is a tool for daily life in modern society. He thus identified that literacy, leading to education, is a dire necessity to cope with life in modern society.

When a woman, whether rural or urban, is empowered educationally, she can transform her environment positively. According to Sharma (2010), an educated woman has the skills, the self-confidence and the information she needs to become a better parent, worker and citizen.

Educating women is a challenge for any organized body, but it is one with prospects of a qualitative future for the entire community of citizens. Educating rural women is even more of a challenge and the prospects are even greater because then, the state as a whole would be taken care of educationally and the impact would be felt state-wide. 
Women constitute an important part of the assets of any state which, as defined by the 2011 IFAD Rural Poverty Report, are essentially a type of asset in which capital is 'embodied' in people. The asset of education would therefore be 'embodied' in these rural women who would in turn transfer their value to their respective environments, thereby making for a better home, a better workplace, a better community and a better Rivers State.

\section{Suggestions/Recommendations}

To make the prospects of educating rural women in Rivers State more viable, a few suggestions or recommendations have been proffered below:

1) Women Development Centres should be set up in various communities with functional classrooms included for continuous and uninterrupted learning;

2) Community libraries and book centres should be established to perpetuate the culture of literacy in women;

3) A wide variety of pertinent subjects should be taught to give rural women a well-rounded education. Such subjects should include: a) health education; b) agricultural science; c) business education; d) computer science; e) civic education; f) social studies; etc.

4) Health practitioners, especially ophthalmologists, should be made to work closely with the women to enable the benefit maximally from the education being given;

5) Micro-credit groups could be organized among the women to alleviate poverty and place them in a position to afford educating themselves;

6) Regular training should be provided by voluntary organizations for project teachers and staff to introduce them to more modern ways of teaching adult pupils. 


\section{References}

Anan, Kofi (2006). Literacy quotes. Retrieved on August 02, 2010 from http:www.betterworld.net/quotes/literacy-quotes.htm

IFAD (2001). The challenge of ending rural poverty. Poverty Report 2001. Oxford University Press, February.

Iyalla-Amadi, P. E. (2009). The impact of indigenous language on basic literacy education in Khalga and Phalga in Rivers State. Unpublished PGDE project. University of Port Harcourt.

Rivers State Ministry of Information and Communication. (2010). Rivers State Diary. EU: Johnson Diaries Ltd.

Sharma, G. (2010). Gender inequality in education and employment. Retrieved on July 24, 2010 from http://www.Yesweb.org/summit/sessions/op.inequality.doc 